\title{
'Die pen is magtiger as die swaard': Oor skrifgeletterdheid, skrifgeleerdes en Israel se Tweede Tempeltydperk
}

\begin{abstract}
Author:
Gerda de Villiers ${ }^{1}$

Affiliation:

${ }^{1}$ Department of Old

Testament Studies,

University of Pretoria,

South Africa

Correspondence to:

Gerda de Villiers

Email:

gerdadev@mweb.co.za

Postal address:

Private Bag X20, Hatfield

0028, South Africa

Dates:

Received: 12 Apr. 2013

Accepted: 31 May 2013

Published: 13 Aug. 2013
\end{abstract}

How to cite this article:

De Villiers G., 2013, “'Die pen

is magtiger as die swaard":

Oor skrifgeletterdheid,

skrifgeleerdes en Israel se

Tweede Tempeltydperk',

HTS Teologiese Studies/

Theological Studies 69(1),

Art. \#1987, 9 pages.

http://dx.doi.org/10.4102/

hts.v69i1.1987

\section{Copyright:}

C) 2013. The Authors.

Licensee: AOSIS

OpenJournals. This work

is licensed under the

Creative Commons

Attribution License.

Read online:

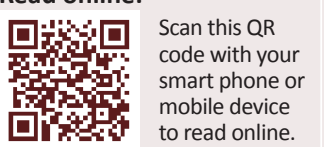

'The pen is mightier than the sword': Literacy and scribes in Israel during the Second Temple period. This article is divided in two parts. Part one examines scribal education and scribes in the ancient Near East and Israel. Although no real evidence exists for scribal schools and education in Israel, it is argued that some form of institutionalised training must have taken place in order to produce literary texts of such a high quality as are found in the Hebrew Bible. Comparative material from Mesopotamia serves to trace the education of scribes in general. Part two focuses on the Second Temple period in ancient Israel. Ezra the scribe emerges as a typical scribe from that era. Post-exilic Israel was grappling with its identity, and sought

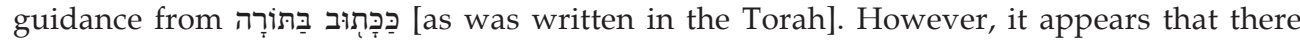
were different interpretations of the written Law during this period. Scribes of the Ezra circle advocated a radical policy of exclusivity on the basis of what was written in the Law; others who wrote the texts of Trito-Isaiah and Ruth pleaded for a more inclusive attitude towards foreigners. The conclusion is that the battle was fought not with the sword, but with the pen, therefore: 'The pen is mightier than the sword.'

\section{Inleiding}

Die Bybel was nooit bedoel om as een mooi storie van begin tot einde gelees te word nie. Sedert Wellhausen se bronnehipotese is dit ondenkbaar om nog te aanvaar dat die Woord van God onfeilbaar en naatloos van die een episode na die ander voortvloei. Inteendeel. As 'n mens die tekste deurlees, blyk dit maar al te gou dat meer as een skrywer hand aan die pen gewaag het om verskillende, selfs teenstrydige tekste daar te stel.

Hierdie artikel gaan twee sake ondersoek: eerstens, wat kan afgelei word oor skrifgeletterdheid en die opleiding van ou Israel se skrifgeleerdes; en tweedens, wat het hulle oor die 'ware Israel' in die tydperk na die ballingskap geskryf? Anders gestel, wie is in die gemeente van die Here 'ingeskryf' en wie is 'uitgeskryf'?

\section{Deel een: Oor skrifgeletterdheid en skrifgeleerdes Die ontwikkeling van'n skrywersklas}

Die ou Nabye-Oosterse beskawing, ou Israel inkluis, was grotendeels ongeletterd. Bitter min mense kon lees en skryf. Hierdie samelewings was mondelinge kulture (Van der Toorn 2007:10). Hulle het vanselfsprekend aanvaar dat hulle op die gesproke woord aangewese is, en daarom het hulle ook nie ' $n$ besondere behoefte aan geskrewe tekste gehad nie (Davies 1998:16). Woorde wat wel in geskrewe vorm neerslag gevind het, is altyd hardop voorgelees, hetsy voor 'n groter of kleiner gehoor, of alleen en privaat geprewel (vgl. Ps 1:2; Van der Toorn 2007:12). Stillees was 'n onbekende oefening; geskrewe tekste was altyd bedoel om die mondelinge voordrag daarvan te ondersteun. Met ander woorde, lees was 'n orale aktiwiteit, woorde moes gehoor word.

Gegee die feit dat mondelinge voordrag primêr was, en die mensdom al gepraat het lank voordat hulle begin skryf het, waarom het die behoefte ontstaan om enigiets op skrif te stel? Die ontwikkeling van skrif gaan hand aan hand met die ontwikkeling van kultuur en beskawing. Namate ' $n$ beskawing van ' $n$ selfonderhoudende, familiegerigte landboustelsel tot 'n hoogs gesofistikeerde stadskultuur met 'n komplekse burokratiese hiërargie ontwikkel, vereis die ekonomiese administrasie van tempels en paleise dat daar van grootskaalse handel boekgehou word (Nemet-Nejat 2002:47), wat aansienlik meer behels het as die gewone ruilhandeltransaksies van 'n agrariese samelewing. Die oudste bestaande geskrewe tekste is 'kwitansies', oftewel bewyse van wat gekoop en verkoop is (Walker 1996:17; Davies 1998:17).

Wie was vir die boekhouding verantwoordelik? Dit was waarskynlik nie die koning of die kultiese hoëpriesters nie, en ook nie die boere vanuit die landbougemeenskap nie. 'n Mens kan die afleiding 
maak dat daar met die proses van verstedeliking 'n bepaalde 'skrywersklas' ontwikkel het. Hulle was nie aan die toppunt van die hiërargie of die leiers van die kultus nie, maar hulle was ten nouste betrokke by wat in die paleis en die tempel gebeur het. Verder moes hulle ook oor ' $n$ bepaalde intellektuele vermoë beskik het, want spoedig sou hulle besef dat skrif nie net vir boekhou tot nut was nie, maar dat dit ook vir ander doeleindes aangewend kon word. Mettertyd het gevorderde geskrewe tekste ontwikkel: koningslyste en geslagsregisters wat vir die argief bewaar moes word; regstekste, wette, reëls en regulasies vir 'n ordelike samelewing; kultiese liedere en gebede; wysheidspreuke en gesegdes, ensovoorts (Davies 1998:17). Die klem was egter by implikasie steeds op mondelinge voordrag, en daarom was daar ook bepaalde stilistiese voorwaardes om die gesproke woord te ondersteun - soos rym, ritme, herhaling, geykte frases, en wat die bepaalde genre ook al vereis het (Van der Toorn 2007:14). Individuele skrywers kon hierdie formules nie uit hul ${ }^{1}$ duim suig nie iewers moes hulle geleer het watter soort teks geskryf moes word, en watter stylfigure daarby hoort.

Om dus saam te vat: in die oorwegend ongeletterde antieke samelewings was die skrywers 'n besondere elitistiese klas: die intelligentsia van hul tyd. Hulle was 'n klein groepie, 'n handjievol mense uit die boonste geledere van die gemeenskap. Hulle het boonop oor kennis en vaardighede beskik wat die res van die gemeenskap nie gehad het nie, nie eens die koning of die priesters nie. En hierdie skryfvaardighede, veral omdat dit ten doel gehad het om mondelinge voordrag te ondersteun, moes aangeleer word.

\section{'n Skrifgeleerde se opleiding}

\section{Was daar skryfskole in ou Israel?}

Danksy die betreklike duursaamheid van kleitablette, is daar volop bewyse van 'skryfskole' in Mesopotamië, en kan die aard van skrifgeleerdes se opleiding met redelike sekerheid nagespeur word. Teen die tyd wat ou Israel tot die ou NabyeOosterse statewêreld toegetree het, was perkament of papirus in gebruik. Ongelukkig, vanweë die harde Palestynse klimaat en die bros aard van hierdie skrifmateriaal, is daar bitter min bewyse van soortgelyke 'skryfskole' in die wêreld van die Ou Testament: die ontdekking van die Qumran-geskrifte kom die naaste daaraan (Van der Toorn 2007:75-76).

Die probleem word verder bemoeilik deur die feit dat die Hebreeuse Bybel nêrens na 'skool' verwys nie. Omdat daar geen duidelike bewyse vir die bestaan van institusionele opleiding vir skrifgeleerdes is nie, word die gevolgtrekking soms gemaak dat daar nie so iets bestaan het nie (vgl. Weeks 1994:153, 156). Na 'n deeglike ontleding van OudHebreeuse epigrafiese bewyse, kom Rollston (2006:67-68) egter tot die gevolgtrekking dat daar wel in ou Israel formele, gestandaardiseerde opleiding bestaan het. 'n Mens kan egter ook andersom redeneer: die afwesigheid van 'n term soos 'skool' impliseer nie noodwendig die afwesigheid van die instelling nie; inteendeel, die hoë literêre kwaliteite van die bestaande tekste in die Hebreeuse Bybel impliseer juis dat die skrywers daarvan die een of ander vorm van opleiding met 'n voorgeskrewe leerplan moes ondergaan (vgl. Tov 2004:13; Van der Toorn 2007:76).

By gebrek aan tasbare bewyse vir institusionele skrifopleiding in ou Israel, maar met die aanname dat dit wel bestaan het, is die naaste vergelykbare materiaal dié van Mesopotamië. Direkte parallelle kan egter nie getrek word nie (Tov 2004:13). Die Mesopotamiese kultuur het lank voor Juda en Israel 'n hoogbloei beleef. In die eerste plek dus het ou Israel se skrywers etlike eeue ná hul Mesopotamiese kollegas begin skryf; in die tweede plek is die Hebreeuse (alfabetiese) skrif aansienlik eenvoudiger as die nagenoeg duisend (selfs meer as die variante ingesluit word) spykerskriftekens wat die Mesopotamiese student moes bemeester; en laastens is dit moontlik dat geletterdheid teen die tyd van die Tweede Tempel meer algemeen as voor die ballingskap was. Skrifopleiding in Mesopotamië gee weliswaar 'n aanduiding van skrifopleiding oor die algemeen in die ou Nabye Ooste, maar wat ou Israel betref, moet bogenoemde faktore in gedagte gehou word.

Skrifopleiding in Mesopotamië (vgl. bv. George 2003:35-39; Carr 2005:23-26; Van der Toorn 2007:54-57)

Behalwe dat die skrifgeleerdes tot die elitistiese klas van die intelligentsia in die samelewing behoort het, het hulle meestal net uit sekere families gekom (Van der Toorn 2007:55). Die kuns van lees en skryf is hoofsaaklik van vader na seun oorgedra (George 2003:37), dog in enkele gevalle is daar bewyse dat meisies ook betrokke was Pearce (1995:2265). Vroue was egter steeds die uitsondering eerder as die reël, veral in die verdere fases van skrifopleiding.

Heel vroeg het die onderrig aan die huis van die vader plaasgevind, maar later het die tempel die sentrum van skrifgeletterdheid geword (Van der Toorn 2007:55-56). ${ }^{2}$ Studente het ' $n$ streng voorgeskrewe leerplan gevolg wat in twee fases verloop het. In die eerste fase moes hulle 'n mooi, leesbare handskrif ontwikkel en met gemak kon transkribeer. Ook moes hulle in staat wees om te kopieer en te memoriseer - enigiets van sillabes, woorde, lyste, spreuke, korter of langer paragrawe uit religieuse tekste (mites) of literêre werke (soos die Gilgameš-epos) (George 2003:36-37; Carr 2005:22-23; Van der Toorn 2007:56-57). Hulle is aan verskeie soorte tekste bekend gestel: wette, administrasie, wiskunde, wetenskap, divinasie, musiek, historiografie ensovoorts. Met ander woorde, hulle moes die tegniese woordeskat van verskillende vakdissiplines ken en bemeester. Alhoewel Akkadies as spreektaal Sumeries vroeg in die ontwikkeling van skrif verdring het, het 'n grondige kennis van die Sumeriese taal- en letterkunde altyd deel van die Mesopotamiese skrywersleerplan uitgemaak (George 2003:35; Carr 2005:2324, 26; Van der Toorn 2007:56). Die ou klassieke taal is nooit verwaarloos nie. Hierdie eerste fase het dus om meer gegaan

2.Crenshaw (1985:608) wys daarop dat die tempel veral die sentrum van leer en onderrig was toe geletterdheid meer algemeen en op die waardes van die middelklas gerig was. 
as om bloot te leer lees en skryf; die student moes veral ook 'n bepaalde kulturele geletterdheid ontwikkel.

Baie studente het sommer vroeg al uitgesak, en dié wat oorgebly het, het ook nie almal die moed gehad om verder te studeer nie (George 2003:36; Van der Toorn 2007:58). Die tweede fase was nog strawwer. Nou moes die studente langer tekste in die geheel memoriseer en kopieer; hulle het ook die geleentheid gekry om in die verskillende vakdissiplines te spesialiseer - byvoorbeeld eksorsisme, astrologie, die komponeer van verskillende kultiese himnes, sang ensovoorts. Blykbaar het slegs $10 \%$ van die studente hierdie tweede akademiese vlak van skrifgeletterdheid geslaag (George 2003:36; Van der Toorn 2007:58).

Maar nog was 't einde niet! Uiteindelik moes die student nog 'n finale eksamen voor die 'Vergadering van Geleerdes' (puhur ummânī) aflê en sy kennis en vaardighede oortuigend bewys. Eers daarna het hy 'n diploma ontvang waarvolgens hy toegelaat is om sy beroep te beoefen (Van der Toorn 2007:59). Dit is baie duidelik dat die ware skrifgeleerdes in die antieke wêreld 'n handjievol akademici was wat 'n grondige kennis van die akademiese, kulturele, literêre en religieuse tradisies van hul samelewing gedra het.

\section{In watter mate is ou Israel vergelykbaar?}

Hierbo is daarop gewys dat dit onverantwoordelik sou wees om direkte parallelle tussen skrifopleiding in Mesopotamië en ou Israel te trek. En ofskoon die Hebreeuse Bybel geen woord of verwysing het na 'skool', 'skoling' of na enige formele institusie wat daarmee verband hou nie, is daar volop sinspelings op die een of ander leer-onderrig-situasie. ${ }^{3}$ Die boek Spreuke wemel daarvan: keer op keer word 'n seun deur sy vader in die wysheid onderrig (vgl. bv. Spr 1:8; 2:1-2; 3:1; 4:1; ens.). Dit weerspieël hoofsaaklik die onderrig wat 'n ouer vir 'n kind gee, maar selfs in hierdie boek kom die verband tussen 'hoor' (mondelinge voordrag), 'onthou' (memoriseer), 'skryf neer' (stel op skrif) en 'doen verslag' (weer 'n mondelinge weergawe) duidelik na vore (Spr 22: 17-21; vgl. Carr 2005:126-127). Dit lyk oënskynlik na informele tuisonderrig; nogtans blyk die tradisionele elemente van onderrig - leer, onhou, gee weer - ook uit hierdie boek.

Meer formele leersituasies was egter ook bekend (Van der Toorn 2007:77): 2 Konings 4:38 vertel van profete wat aan Elisa se voete gesit het, en in Esegiël 8:1 sit die leiers van Juda voor die profeet. Albei hierdie tekste het vermoedelik op 'n leersituasie betrekking. Lyste, soos byvoorbeeld die lyste van die rein en onrein diere in Deuteronomium 14 en Levitikus 11, is vergelykbaar met die Babiloniese leksikale en ander lyste. Daar is ook tekste wat 'n bepaalde regskennis veronderstel, soos die prosedures vir die koop en verkoop van grond (Jer 32:9-15), en skei en hertrou (Deut 24:1; Jes 50:1; Jer 3:8; kyk ook Crenshaw 1985:604).

3. למד [leer] kom as selfstandige naamwoord sowel as werkwoord in verskillende stamformasies voor. Sien byvoorbeeld die woordeboek van Holladay (1988:177). Verskillende teksverwysings word ook aangedui.
Maar wat dan van 'skrifgeleerdes' - of skrywers? Die Hebreeuse woord sôpēr of sōpēr word in Afrikaans op meer as een manier vertaal, maar alles het betrekking op iemand wat geskryf het. Van der Toorn (2007:77-79) toon enkele gevalle van sôper $r$-spesialiserings binne die skrywersberoep self aan. Die mees voor die hand liggende voorbeeld van iemand wat as 'skrywer' optree, is Baruch, wat geroep word om die profeet Jeremia se woorde op te teken (Jer 36). Anders gestel, Jeremia het van 'n professionele skrifgeleerde gebruik gemaak om op te skryf wat hy gesê het. Moontlik was Baruch vergelykbaar met iets soos ' $n$ professionele persoonlike sekretaris.

Dan was daar ook skrywers aan die koninklike hof, wat die amp van 'staatsekretaris' beklee het (vgl. 2 Sam 8:17; 1 Kon 4:3; 2 Kon 18:18; 2 Kon 22:3; Crenshaw 1985:604). Hulle het ' $n$ besonder hoë rang beklee en moes notule hou van alle gebeure aan die koninklike hof. Verder was hulle ook verantwoordelik vir binne- en buitelandse korrespondensie namens die koning. ${ }^{4}$ Met ander woorde, hulle kan vergelyk word met staatsamptenare in die diplomatieke diens (vgl. ook Davies 1998:18).

In die tydperk van die Tweede Tempel tree Esra, die priester, egter tot die geledere van die skrifgeleerdes toe. Esra en ander skrifgeleerdes van hierdie tyd se rol word meer in die volgende afdeling van die artikel toegelig.

\section{Samevatting}

Voorlopig 'n kort samevatting oor wat in die algemeen gesê kan word oor skrifgeletterdheid in ou Israel. Alhoewel 'n mens baie versigtig moet wees om direkte parallelle tussen skrifopleiding in Mesopotamië en ou Israel te trek, is daar bewyse $^{5}$ dat die Israelitiese skrifgeleerdes wel die een of ander vorm van formele onderrig ontvang het. Selfs al was geletterdheid in die tydperk van die Tweede Tempel meer algemeen as in Mesopotamië, het dit heel waarskynlik nie veel verder gestrek as die vermoë om 'n naam te kan skryf of om graffiti iewers op 'n muur of 'n rots aan te bring nie. Die kundige formulering van bepaalde soorte tekste, en veral die vermoë om tekste te interpreteer en te herinterpreteer - wat veral tydens die Tweede Tempelperiode gebeur het - vereis 'n besondere vlak van opleiding. Alles dui daarop dat die professionele skrywersklas van ou Israel die een of ander formele, gestandaardiseerde opleiding ondergaan het, met moontlike rigtings waarin hulle kon spesialiseer.

4. Soos reeds hierbo (voetnoot 1) aangedui, het skrywers in die antieke wêreld altyd anoniem geskryf. Van der Toorn (2007:33-36) onderskei die volgende vorms van 'anonimiteit': honorêre outeurskap - wette of briewe wat in die naam van die koning geskryf is, is heelwaarskynlik in opdrag van hom deur anonieme professionele skrifgeleerdes geskryf, byvoorbeeld die wette van Hammurabi of ander diplomatieke korrespondensie; pseudonieme outerskap - wanneer 'n skrywer onder die naam van ' $n$ werklike of fiktiewe figuur uit ' $n$ glorieryke verlede skryf om gesag aan sy dokument te gee, byvoorbeeld in die boek Deuteronomium lê een of ander skrywer in werklikheid sy eie woorde in die mond van Moses; toegeskrewe outeurskap byvoorbeeld die Psalms van 'Dawid', die Spreuke van 'Salomo'.

5.Crenshaw (1985:604) dui ook die volgende tekste aan as getuienis wat geletterdheid wel in ou Israel bestaan het: Rigters 8:13-17 vertel van Gideon wat' $n$ jongman van Sukkot vang, en wat vir hom die name van die leiers van die stad opskryf; in Jesaja 8:16 gee Jesaja opdrag aan sy volgelinge om eers stil te bly oor wat hy hulle geleer 8:16 gee Jesaja opdrag aan sy volgelinge om eers stil te bly oor wat hy hulle geleer het; Job versoek in Job 31:35 dat iemand wat' $n$ klag teen hom het, dit op skrif moet (2:2) om sy openbaring op kleitablette te skryf sodat die mense dit kan lees. 


\section{Deel twee: Tweede Tempelperiode Judeërs of Israeliete?}

Die geskiedenis is bekend. Ná Salomo se dood het die verenigde monargie $^{6}$ tussen die Noordryk en die Suidryk - oftewel Israel en Juda - geskeur. In 721 v.C. buig Israel die knie voor die Assiriërs (vgl. bv. Boshoff 2000a:102, 2000b:117). Dié wat in ballingskap gegaan het, sowel as dié wat agtergebly het, het tot so 'n mate met die Assiriërs vermeng dat Israel vir alle praktiese en historiese doeleindes van die toneel verdwyn het (Barton \& Bowden 2004:131).

Met Juda was dit 'n bietjie anders. Die Babiloniërs wou nie die totale bevolking uitwis nie, maar hulself hoofsaaklik teen opstand en revolusie beskerm (Le Roux 1987:119). Nie een nie, maar twee deportasies het plaasgevind. Die finale slag was 586 v.C. (vgl. Le Roux 1987:117-120; Boshoff 2000b:117) waartydens Jerusalem vir eens en altyd - of so het dit gelyk deur koning Nebukadneser van Babilonië verwoes is. Tydens albei geleenthede is die boonste laag van die samelewing die koning, adel, hoëpriesters en militêre korps - afgeskep en na Babilonië toe weggevoer (Le Roux 1987:101). ${ }^{7}$ Hier is hulle toegelaat om in kolonies te bly, en anders as in die geval van Israel in Assirië, het hulle nie geassimileer nie, maar hul identiteit behou. Hulle het meer as net hul identiteit behou: alhoewel die ballingskap 'n diep en donker tyd in die geskiedenis van Juda was, het hulle gedurende hierdie periode van ballingskap ernstig oor hul identiteit en hul godsdiens besin, en dit het neerslag gevind in hul geskrifte die grootste gedeelte van die latere Hebreeuse Bybel (Barton \& Bowden 2004:140).

Vir die ballinge en vir dié wat agtergebly het, het dit gelyk asof alles misluk het. Tóg het die geleerdes onder hulle uit die ramp probeer sin maak. Hulle het weer na die stories van Israel se verlede gekyk, en hoop geput uit die verbond wat God met sy volk gesluit het. Dit het egter gebeur nog voordat Israel 'n volk was en voordat hulle 'n koning gehad het: God alleen was koning. Hierdie donker tyd was ironies genoeg die ideale tyd om die spesiale verhouding met God te herontdek. Die stories van Israel se verlede is versamel en op só 'n wyse weergegee om die mense te herinner aan wat God in die verlede vir hulle gedoen het. Daardeur kon hulle hoop vir die toekoms skep. God sou trou bly aan sy mense (Barton \& Bowden 2004:141).

In 539 v.C. kom die verrassende wending: Kores, die Persiese koning neem Babilonië in, en anders as die ander volke, volg hy 'n beleid van verdraagsaamheid en selfs respek vir die kulturele en godsdienstige gebruike van die oorwonne volke (Le Roux 1987:140). Enkele jare na sy oorname is hy selfs gewillig om die ballinge toe te laat om na hul tuisland terug te keer, en hul stad en tempel te herbou. Uiteraard was hierdie oënskynlik groothartige gebaar nie uit medemenslike

6.Boshoff (2000a:97) wys op toenemende getuienis dat die bevolkingsgroepe in die noorde en die suide van die land waarskynlik nooit werklik verenig was nie - hul opvattinge oor God, koningskap en die samelewing was te verskillend.

7.Williamson (2010:117-121) reken dat nie al die adellikes en priesters na Babel toe weggevoer is nie, sommige het wel in die land agtergebly. Die krisis was eerder da families - ook koninklike families - opgebreek is. deernis gebore nie; die Persiese owerhede het inteendeel 'n baie duidelike politieke agenda gehad. Hulle wou hul grondgebied uitbrei, nie ter wille van die plaaslike bevolkings nie, maar om die nodige inkomstebelasting in te voer en daardeur die magtige regering in stand te hou (Davies 1998:65). Die welwillendheid om die ballinge te laat terugkeer met die toegewing om hul stad en tempel weer op te bou, was in die eerste plek 'n fyn diplomatieke skuif. Die ballinge mag na hul land toe terugkeer, en selfs deur hul eie mense regeer word: in ruil daarvoor ontvang die Perse die ballinge se dankbaarheid, lojaliteit en natuurlik die nodige belasting.

Die ballinge het ook nie oornag en masse teruggekeer nie. Dit was 'n proses wat ongeveer 'n honderd jaar of selfs langer geduur het (Davies 1998:65). En ook nie almal het teruggekeer nie. Onder die diplomatieke Persiese regering was daar van die ballinge wat hulself goed ingegrawe het en selfs opgang in die regering se administrasie gemaak het. Hulle was onwillig om 'n gerieflike, stabiele bestaan prys te gee ter wille van 'n gesukkel in 'n tuisland wat min of meer van die grond af opgebou moes word.

Hierdie ballinge - dié wat na die land toe teruggekeer het, sowel as dié wat in Babilonië agtergebly het - was uitsluitlik die nageslag van die stamme van Juda en Benjamin, en die Levitiese priesters. ${ }^{8} \mathrm{Na}$ aanleiding van die Persiese provinsiebenaming Jehud, soos daar na die tuisland verwys is, sou ' $n$ mens verwag dat die tekste wat ná die ballingskap in die Hebreeuse Bybel neerslag gekry het, hoofsaaklik van 'Judeërs' of selfs 'Jode' praat. Dit is egter nie die geval nie. Die Pentateug - altans van Eksodus tot Deuteronomium gebruik uitsluitlik die term 'Israeliete' vir die volk. Ook die boek Esra praat van feitlik deurgaans van 'Israeliete' as Esra met die volk praat (vgl. Grabbe 2004:170). In werklikheid is die posteksiliese 'Israeliete' dus eintlik 'Judeërs' en 'Benjaminiete'; die Levitiese priesters het om die een of ander rede hul identiteit behou. Wat sou die rede(s) wees?

Grabbe (2004:168-171) bied 'n aantal moontlike verklarings. In wese kom dit daarop neer dat die term 'Israeliete' 'n literêre en teologiese oogmerk het. Die skrywers van die tekste wou 'n bepaalde identiteit van die diverse inwoners van die provinsie Jehud beklemtoon, maar dit ook koppel aan die Joodse gemeenskappe elders in Mesopotamië. Moontlik het hulle teruggegryp op die gemeenskaplike voorvader Jakob (Israel); of na 'n idealistiese tydperk in die geskiedenis toe Juda en Israel ' $n$ verenigde monargie was. Wat die redes ook al mag wees, die doel is duidelik: die posteksiliese 'Joodse' gemeenskap, in en buite die provinsie Jehud (Juda), sou hul identiteit binne 'n teologiese 'Israel' vind.

\section{Die identiteit van die 'ware Israel'}

Teen hierdie tyd behoort die mag van die skrywersklas duidelik te blyk. Hoewel hulle nie die magtige charismatiese volksleiers is nie, het hulle nogtans net soveel invloed, indien nie meer nie. Dit is die skrywers wat die tekste skryf en interpreteer, en ten spyte daarvan dat hulle deurgaans 8.Hierdie gegewens, soos weergegee in die Hebreeuse Bybel, dra ook'n ideologiese kleur. 
anoniem bly, kan hulle besluit wat die naam van 'n volk gaan wees. En nadat hulle vir die volk 'n naam gegee het, gaan hulle ook besluit hoe die identiteit van die volk gaan lyk.

Juis dít was een van die grootste probleme in die tydperk van die Tweede Tempel: die kwessie van identiteit, die kwessie van die 'ware Israel' (vgl. Grabbe 2004:168; Gerstenberger 2005:332; Leuchter 2010:60; Scharper 2011:36). Sekere aangeleenthede is voor die hand liggend: in die eerste plek moet die Torah - oftewel die Wet van Moses - in alle opsigte nagekom word. Dit sluit byvoorbeeld in onderhouding van die Sabbat, besnydenis, dieet, religieuse feeste, ensovoorts (Gerstenberger 2005:332). Diegene wat hierdie verordeninge nakom, is deel van die gemeente van die Here, die ware Israel; diegene wat hulle nie aan die bepalinge steur nie, word uit die kring uitgeskuif.

Die probleem kan egter ook anders gestel word: wat sou die suiwerheid van die ware Israel kon bedreig? Een van die hardste antwoorde hierop word in die boeke Esra en Nehemia gegee: huwelike met vreemde vroue: ${ }^{9}$

$[D]$ ie mense van Israel en die priesters en die Leviete het hulle nie afgesonder van die 'volke van die lande' met sy afskuwelike gebruike nie ... Hulle het van húl dogters vir hulself en hul seuns geneem, sodat die heilige saad hom met die volke van die lande vermeng het. (Esra 9:1-2; vgl. Knoppers 2011:170)

Hierdie volke is die Kanaäniete, Hetiete, Feresiete, Jebusiete, Ammoniete, Moabiete, Egiptenaars en Amoriete. ${ }^{10}$

In die posteksiliese tyd staar Israel se suiwer identiteit as 'volk van God' 'n ernstige bedreiging in die oë: die teenwoordigheid van heidense volke in die gemeente van die Here, en veral huwelike met hul dogters.

\section{Esra se dubbele persoonlikheid}

\section{Esra die Sadokitiese priester}

Esra word vanaf Babilon afgevaardig om die 'Wet van Moses' vir die volk wat in die provinsie Jehud woon, te leer (Esra 7:1-10). Dit blyk egter dat hierdie Wet vir 'n baie lang tyd verwaarloos is, soveel so dat die gemeente by die aanhoor daarvan tot trane gedryf word (Neh 8:10; vgl. Pakkala 2011:81). Maar wie was hierdie Esra? ${ }^{11}$

Esra verskyn pas op die toneel, dan volg sy indrukwekkende geslagsregister: sy genealogie word 'n volle sewentien geslagte terugherlei tot by Aäron, die heel eerste hoëpriester. ${ }^{12}$ Soos alle geslagsregisters in die Hebreeuse Bybel is ook Esra

9.Die hele volume Mixed marriages, intermarriage and group identity in the Second Temple period (2011) onder redaksie van Christian Frevel word aan die probleem van gemengde huwelike ten tye van die Tweede Tempelperiode gewy.

10.Die volke in hierdie lys dui op Israel se argetipiese vyande voor die intog en kom ook elders in die Pentateug voor (vgl. Gen 15:19-21; Eks 3:8, 17; 33:2; 34:11; Deut 20:17). Die lys is waarskynlik anakronisties. Tydens die posteksiliese tydperk het slegs die Ammoniete, Moabiete en Egiptenare bestaan (Southwood 2011:52)

11.Barton en Bowden (2004:145) wys daarop dat Esra heel waarskynlik 'n fiktiewe figuur is. Hy speel byvoorbeeld buiten in die boek Esra nie ' $n$ noemenswaardige rol nie; historiese gegewens klop nie heeltemal met die aanduidings in die boek Nehemia nie. Moontlik is Esra' $n$ karakter wat die 'Wet' verpersoonlik.

12.Esra ... seun van Seraja, Asarja, Gilkija, Sallum, Sadok, Agitub, Amarja, Asarja, Merajot, Seragja, Ussi, Bukki, Abisua, Pinehas, Eleasar, Aäron (Esra 7:1-5). s'n histories onbetroubaar en onakkuraat. Sy ononderbroke priesterlike herkoms word deur ongeloofwaardige - selfs onbekende - lyne herlei. Die doel is egter duidelik: om Esra as 'n prominente Sadokitiese priester uit te beeld (Leuchter 2010:44). Uit hierdie geslagsregister blyk sy religieuse, kulturele en politieke mag. Hy het genoegsame outoriteit om hom op die Torah te beroep sodat die volksidentiteit gesuiwer en die kultus gereinig kan word (Quesada 2002:34).

Sekere name in hierdie gefabriseerde genealogie is egter insiggewend: Esra word voorgestel as 'seun van Seraja'. Dit kan nie 'n direkte biologiese vader-seun-verband wees nie (Leuchter 2010:47). Indien dit dieselfde hoëpriester Seraja van 2 Konings 25:18 is, dan het hy tydens die regering van Sedekia gedien. Hy is egter in Ribla tereggestel, en het dus nie die ballingskap meegemaak nie. Nietemin was hy die laaste hoëpriester van pre-eksiliese Juda. Deur hom word Esra aan die pre-eksiliese en eksiliese gemeenskap gekoppel.

Uiteraard is Sadok 'n baie belangrike figuur. Histories gesproke hoort Sadok tot die hoogbloeityd van die monargie, die roemryke tyd van Dawid en Salomo. Kyk 'n mens egter na die geslagsregister, is hy slegs vier geslagte van Esra verwyder. Dit is nog ' $n$ aanduiding dat hierdie geslagsregister nie histories geloofwaardig is nie (Leuchter 2010:46). Sadok verteenwoordig egter die ideologiese tydperk van Dawid en Salomo ${ }^{13}$ en die noue verbintenis tussen Sadok en Esra tel amptelik in Esra se guns: hy word verklaar as deel van die regerende priesterskap wat lank met die tempel geassosieer is.

En dan is daar Pineas. Pineas dateer uit die woestyntyd. Numeri 25:6-9 vertel die grusame verhaal wat hier afgespeel het. 'n Israelitiese man het 'n Midianitiese vrou in die gemeenskap van die Here ingebring. Toe Pineas sien wat aan't gebeur is, het hy opgestaan, sy spies gevat en die man en vrou in die vrouetent deur hul onderlywe deurboor. ${ }^{14}$ Hierdie anekdote het direk betrekking op die vraagstuk oor gemengde huwelike (Fischer 2001:92; Quesada 2002:24; Collins, 2003:13), en weerspieël die priesterlike ywer waarmee gepoog is om beheer oor ' $n$ etnies suiwere Israel uit te oefen. ${ }^{15}$

Laastens herroep die lang lyn wat Esra via Sadok met Aäron verbind, ook die woestyntyd. Die Here bepaal dat Aäron en sy seuns die gesalfde priesters is, en dat die stam van Levi hulle moet dien (vgl. Num 3:6; Leuchter 2010:46). Vir 'n volle sewentien geslagte dus, kan daar 'n direkte lyn getrek word wat Esra op meer as een manier aan die belangrikste hoëpriesters van die volk verbind.

13.Die kunsmatige nabyheid tussen Esra en Sadok mag dalk ook dui op'n tyd toe verskillende priesterlike families, veral die Sadokiete, met mekaar meegeding het om dominansie in Jehud se godsdienspolitiek (Leuchter 2010:46).

14. Hulle is deur die geslagsorgane deurboor (Quesada 2002:25). Hier is egter iets teenstrydig. Moses se Midianitiese verbintenis, sy huwelik met Sippora, dogter van 'n Midianitiese hoëpriester (Eks 2:21) skrei daarteen dat hy hierdie optrede sou goedkeur. Quesada (2002:34) reken dat die status van Aäronitiese priesters verhef is omdat Moses se gewildheid in sekere kringe afgeneem het. Daarom word hy bloot 'n 'profeet' genoem (Deut 34:10).

15.Collins (2003:12-13) lê'n verband tussen Mattatias se optrede (1 Makk 1:26) en dié van Pineas. Dit het nie soseer om geweld gegaan nie, maar daaroor dat Pineas hom vir die saak van die Here beywer het en gepoog het om vir die volk se oortredinge vir die saak van die Here beywer het en gepoog het om vir die volk se oortredinge
- verhoudings met vreemde vroue - te versoen. Ware priesterskap is daardeur gekenmerk. 
Die doel van die geslagsregister is duidelik. Esra is 'n afstammeling van die Sadokitiese priesterklas wat in ballingskap weggevoer is. Die genealogiese inligting verklaar hom besonder bevoeg om ' $n$ leiersposisie binne die priesterlike gemeenskap van Jehud te beklee; des te meer nie bloot omdat hy 'n Sadokiet is nie, maar omdat hy uit 'n familie stam wat deur 'n ononderbroke lyn op die hoëpriesterskap in Jerusalem aanspraak kan maak (Leuchter 2010:47). Sedert Pineas se dae, beywer hierdie lyn van priesterskap hom waarskynlik daarvoor om die volk se etniese identiteit te bewaar. Wie is meer geskik as Esra?

\section{Esra, die Levitiese skrifgeleerde}

Direk na Esra se indrukwekkende geslagsregister wat hom onmiskenbaar as 'n geloofwaardige Sadokitiese priester voorstel, word daar van hom gesê dat hy "n geleerde man, kundig in die wet van Moses' was 'wat deur die Here die God van Israel gegee is' (Esra 7:6). Hierdie beskrywing teken Esra as ' $n$ 'akademikus', een van die geleerdes van sy tyd, dus 'n skrifgeleerde wat die hoogste fase van opleiding ondergaan en geslaag het, en wat in die Torah gespesialiseer het.

Wie was die skrifgeleerdes?

Volgens Deuteronomium 33:10 ${ }^{16}$ is die Leviete by uitstek die leermeesters - plaaslike eksegetiese skrifgeleerdes (Van der Toorn 2007:92). Hulle is ook bedienaars van die kultus, of was dit altans, voor die val van die Noordryk. Toe val Samaria, en baie van die priesters het na die Suidryk gevlug om 'n heenkome by die tempel in Jerusalem te soek. Uiteraard ontstaan daar 'n spanning tussen die vlugteling-priesters van Israel en die gevestigde priesters van Juda (Van der Toorn 2007:93). Wanneer Josia die kultus in Jerusalem sentraliseer, ontstaan daar nóg meer spanning tussen die priesters by die tempel self, en dié by die ander heiligdomme - wat skielik tot niet gemaak moet word (vgl. 2 Kon 23:8).

Die skisma tussen die Levitiese priesters word op die spits gedryf met die Babiloniese ballingskap. Sommige is weggevoer Babel toe, ander het in die tuisland agtergebly. Esegiël, die woordvoerder namens die priesterlike elite wat uit Jerusalem na Babilon weggevoer is, stel dit onomwonde:

Net die Levitiese priesters uit die geslag van Sadok het die dienswerk in my heiligdom onderhou toe die Israeliete My verlaat het. Hierdie priesters mag in my teenwoordigheid kom en dienswerk vir My verrig, hulle mag in my diens staan en vir My vet en bloed as offer aanbied. (Eseg 44:15; Van der Toorn 2007:93)

Esegiël impliseer dus dat slegs die Levitiese priesters wat van Sadok afstam, die ware priesters is wat deurentyd getrou gebly het toe die res van die kinders van Israel tesame met die ander Leviete afgedwaal het. Daarom word dié Leviete gedegradeer tot 'wagte by die tempelpoorte en tempelbediendes' (Eseg 44:11), en mag hulle nie in die teenwoordigheid van die Here kom om priesters in sy diens te wees nie (v. 13). Esegiël beaam dus wat Numeri (3:6) bepaal: daar is 'n hoër priesterlike klas wat deur die ander gedien moet word (vgl. ook Barton

16. Hulle sal vir Jakob in u bepalings onderrig, vir Israel in u wet. Van der Toorn (2007:92 reken dat die name Jakob (Israel) op die vooreksiliese Noordryk dui, toe die Levitiese priesters onderrig gegee het en kultiese bedienaars was.
\& Bowden 2004:171). Sommige tekste poog wel om hierdie ongelykheid tussen twee priesterlike klasse uit die weg te ruim. Deuteronomium 18:6-8 is byvoorbeeld baie duidelik daaroor dat al die priesters op gelyke vlak verkeer: ál die Leviete is broers, elkeen moet ' $n$ gelyke aandeel geniet (Van der Toorn 2007:93). Ook 'n latere teks soos Maleagi (2:5-7) tref nie 'n onderskeid tussen verskillende Levitiese priesterklasse nie. Wat Maleagi betref, is al die Leviete betroubaar om die volk te leer en onderrig in die Wet te gee.

Wat waarskynlik wel gebeur het, was dat daar met die Babiloniese ballingskap nie net 'n verdeling ontstaan het tussen die Leviete wat in ballingskap gegaan het en dié wat agtergebly het nie, maar ook 'n verdeling van pligte (Leuchter 2010:50). Dié wat agtergebly het, moes worstel om die kultus in Jerusalem en ook elders in Juda in stand te hou, die bietjie wat daarvan oor was en nie heeltemal deur die Babiloniese magte verniel is nie. Diegene wat in ballingskap gegaan het, was ver van huis en haard, ver weg van die bekende bande met die tuisland. In die vreemde het hulle gesofistikeerde literêre en eksegetiese metodes onwikkel wat as sodanig hul middel van toewyding geword het (Leuchter 2010:51). Met ander woorde, 'literêre eksegese' word die wyse waarop hulle hulself aan die kultus toewy, bestaande tekste herinterpreteer en sodoende nuwe tekste skep. Juis dit bemagtig die Leviete om op gesaghebbende kennis, interpretasie en onderrig van die Torah aanspraak te maak. Hier in Babel, ofskoon hulle 'n beeld voorhou dat hulle heeldag geween het en nie kon sing nie - aldus Psalm 137 - formuleer die Leviete die skriftelike eksegetiese middele vir 'n gemeenskaplike volksidentiteit. ${ }^{17}$

Dit lyk dus asof daar net na die ballingskap groot konflik was tussen die priesters wat in Jehud agtergebly het, en die meer 'geleerdes' wat teruggekeer het. Mettertyd het hierdie konflik ontplooi in die vorm van 'n arbeidsverdeling: aan die een kant die Leviete, en aan die ander kant die tradisionele Jerusalemse priesterskap wat direk van Sadok afstam (Van der Toorn 2007:94). Aanvanklik het die Sadokitiese priesters 'n hoër status in terme van die tempelhiërargie geniet, omdat hulle ' $n$ groter betrokkenheid by die heilige rituele gehad het (Eseg 44:15). Die 'laer' Leviete se verantwoordelikhede was om onderrig in die Torah te gee, om reg en geregtigheid te laat geskied, en daarmee saam was hulle ook die tempelsangers en bewaarders van die heiligdom.

Op die lang duur sou die invloed van die Leviete egter veel groter as dié van die Sadokiete word. Namate die godsdiens van die Jode toenemend ' $n$ boekgodsdiens geword het, het die mag verskuif van dienaars van die altaar, na hulle wat die geskrewe tradisie ken en die sleutel tot die interpretasie daarvan bewaar het (Leucther 2010:52).

Esra, die geleerde man, kundig in die Wet van Moses, doen presies wat 'n Levitiese priester moet doen. Sy primêre taak is om die Wet weer vir die Israeliete te leer sodat hulle dit kan onderhou. Hy tree op soos wat van 'n Levitiese priester

17. Dit is tog interessant dat daar volgens Esra 8:15 onder Esra se gevolg, bestaande uit die terugkerende ballinge, geen Leviete was nie. 'n Mens sou dus kon aflei dat die meeste van hulle inderdaad verkies het om in Babel agter te bly waar hulle' $n$ hoë mate van aansien, gesag en invloed geniet het (Leuchter 2010:51), of dat die hoë mate van aansien, gesag en invloed geniet
skrywers verkies het om hulle bloot te verswyg. 
verwag word: hy lees die Wetboek van Moses vir die Israeliete voor (Neh 8:5-9 - let wel, steeds 'n orale kultuur), en die ander Leviete verduidelik dit vir hulle (Leuchter 2010:54).

\section{Samevatting van 'Esra, die geleerde man'}

Die konflik tussen Sadokitiese priesters en Levitiese eksegete word dus binne ses verse in die boek Esra (7:1-6) opgelos. Esra is albei. Esra se priesterlike lyn kan bo verdenking herlei word na Aäron. Hy kom wel uit die geslag wat waarskynlik in ballingskap gebore is, maar sy bande met die vooreksiliese hoëpriesters kan nie in twyfel getrek word nie. Verder, in sy geslagsregister is dit duidelik dat hy (via Pineas) 'n kampvegter vir Israel se unieke identiteit sou wees - gesuiwer van enige vreemde en heidense invloede. Die belangrikste van alles is dat Esra ook daarin gespesialiseer het om die Wet van Moses in die fynste detail te ken en te kan uitlê. Hy kan dit met gesag doen, want hy is 'n geleerde man. Esra is duidelik iemand wat tegelyk 'n eerbiedwaardige Sadokitiese priester en ook volledig 'n geskoolde, boekgeleerde Leviet is: hy ken die geskrewe woord, en hy hou in sy hand die sleutels waarmee dit ontsluit kan word. Hy weet wat in die Torah geskryf staan, en hy weet ook hoe om dit uit te lê.

\section{- [soos geskryf in die Torah]}

Maar wat presies is in die Torah geskryf?

Wat Israel se identiteit betref, is Deuteronomium 23:1-3 'n sleutelteks:

Iemand wie se geslagsorgane verbrysel is, of iemand wat ontman is mag nie lid van die gemeente van die Here wees nie. Niemand wat gebore is uit ontoelaatbare geslagsgemeenskap mag lid van die gemeente van die Here word nie, selfs nie so persoon se tiende nageslag nie. Geen Ammoniet of Moabiet mag lid van die gemeente word nie. Niemand uit hulle nageslag mag ooit lid van die gemeente word nie, selfs nie eers van die tiende geslag nie. ${ }^{18}$

In die boeke Esra en Nehemia is daar volop verwysings na Torah, Wet van Moses, Wet van die Here, Wet van God, Boek van Moses, Boek van die Torah. ${ }^{19}$ Nehemia 13:1 beaam Deuteronomium byvoorbeeld feitlik woordeliks: uit die boek van Moses (Torah) is daar vir die volk voorgelees en daar is 'geskryf gevind dat 'n Ammoniet of Moabiet nooit in die

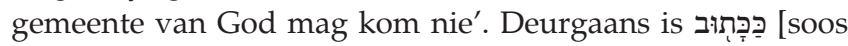
geskryf] die sleutelformule.

Wat presies word onder Torah of 'Wet van Moses' verstaan? Is dit hoofsaaklik die Mosaïese wetgewing soos wat dit in die Pentateug voorkom? Dit blyk nie so te wees nie. Volgens Esra 6:18 het hulle (die ballinge en ander wat teruggekeer het) 'die priesters aangestel volgens hul afdelings en die Leviete volgens hul afdelings vir die diens van God in Jerusalem volgens die voorskrif van die "Wet van Moses"'; en Nehemia 10:34 skryf dat:

die priesters en Leviete en die volk het die lot gewerp oor die lewering van hout ... om dit te bring na die huis van God om vuur te maak ... soos geskrywe staan in die wet.

18.Die redes waarom die Edomiete en Egiptenare nie summier weggewys mag word nie (vv. 7-8), val buite die bestek van hierdie artikel.

19.Vergelyk Esra 3:2; 7:6, 10: Nehemia 8:1, 2, 3, 7-9, 13, 14, 18; 9:3, 14, 26, 29, 34; 10:30, 35, 37; 12:44 (Scharper 2011:31).
Nêrens in die Pentateug of elders word verwysings na hierdie bepalings gevind nie. Dit wil inderdaad voorkom of

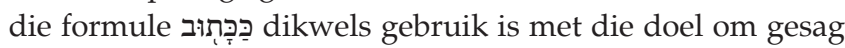
aan 'n bepaling te verleen, selfs al het daardie bepaling of nie in enige geskrewe vorm of glad nie bestaan nie (Scharper 2011:32). Geskrewe tekste, veral geskrewe wettiese tekste,

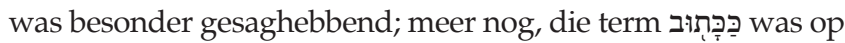
sigself gesaghebbend genoeg om outoriteit aan ongeskrewe bepalings te verleen.

Dit is dan die mag op grond waarvan Esra, die Sadokiet cum skrifgeleerde-Leviet, optree: hy is 'n kenner van die geskrewe Wet van Moses en hy interpreteer hierdie Wet om te bepaal wie is die volk van Israel wat tot die gemeente van die Here behoort. Volgens Esra en Nehemia is groepidentiteit ten nouste gekoppel aan die Wet en die mate waarin Israel daaraan gehoorsaam is (Pakkala 2011:82). Die Wet het Israel anders as die nasies gemaak. Israeliete het hulle egter al hoe minder aan die Wet begin steur, onder andere deur vreemde vroue te vat wat vreemde gebruike ingevoer en Israel se unieke identiteit as volk bedreig het. ${ }^{20}$ Israel kan slegs suiwer bly as elke geskrewe letter van die Wet nagekom word.

Maar dan word ' $n$ verrassende teenstem gehoor:

En laat die uitlander wat hom by die Here aangesluit het, nie spreek en sê: Die Here sal my gewis afskei van sy volk nie; en laat die ontmande nie sê: Kyk, ek is 'n droë boom nie. (Jes 56:3)

En nog 'n skrywer skryf 'n roerende verhaal van 'n Moabitiese vrou se onbaatsugtige lojaliteit teenoor haar Judese skoonmoeder terwyl hulle in die ellendigste situasie denkbaar verkeer: die boek Rut wek simpatie, selfs bewondering, vir hierdie vreemde Moabitiese vrou, en is 'n sprekende voorbeeld van 'n teenstorie ('Gegengeschichte' - Braulik 1999:18) om Esra en Nehemia se interpretasie van die Deuteronomium-teks te weerspreek. Van die Ammoniet Agior se dapper optrede teenoor Holofernes en sy opname in die gemeenskap van die Israeliete word in die (apokriewe) boek van Judit vertel.

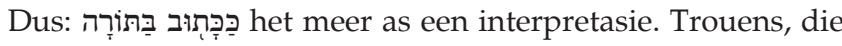
vertolkings van wat in die Torah geskryf is, staan lynreg teenoor mekaar. Hierdie spanning verklap twee verskillende religieuse groepe wat deur verskillende belange aangevuur word (Scharper 2011:30). Om terug te keer tot die heel basiese vraag: dit gaan om Israel se identiteit - wie is deel van die gemeente van die Here, en wie nie? En die antwoord word

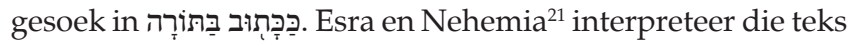
op 'n bepaalde manier; Jesaja, ${ }^{22}$ Rut en Judit ${ }^{23}$ interpreteer dit

20.Pakkala (2011:82) wys daarop dat Esra se sending na Jerusalem nie primêr was om gemengde huwelike te ontbind nie, maar om die Wet vir die Israeliete te leer sodat hulle dit kon onderhou. Gemengde huwelike het gevolg omdat die Israeliete vergeet het wat die Wet daaroor sê. Die heftigheid waarmee Esra en Nehemia teen gemengde huwelike optree, laat egter blyk dat dit inderdaad' $n$ voortdurende probleem gedurende die Persiese tydperk was (vgl. Nihan 2011:68).

21.En ook Esegiël; vergelyk byvoorbeeld Esegiël 44:6-7.

22.Jesaja $55: 3-5 ; 56: 3-8 ; 59: 21 ; 61: 8$.

23.Judit is'n baie laat boek, en reageer waarskynlik nie direk op Esra of Nehemia nie. Dis ook onmoontlik om af te lei hoe lank die debat rondom gemengde huwelike voortgeduur het. Veral Juda se genealogieë in die Kroniekeboek weerspieël'n etniese diversiteit, sonder dat enige oordeel daaroor uitgespreek word (vgl. Nihan 2001:68). 
anders. Ook vir hierdie laasgenoemde groep is van deurslaggewende belang, maar in dié sin dat hulle die terme heeltemal vermy (Scharper 2011:31). Dit is besonder insiggewend dat tekste wat 'n inklusiewe gemeenskap voorstaan, direk teen die bepalinge van die Torah ingaan, sonder om dit pertinent uit te spel. Ofskoon hierdie tekste met Torah-tekste in gesprek tree, of op die streng maatreëls van die Wet van Moses reageer, verwys hulle nooit direk daarna nie. Nêrens gebruik hierdie skrifgeleerdes die terme

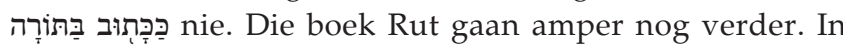
hierdie verhaal wat in 'n landelike milieu afspeel, is stad en tempel opvallend bykans afwesig (Fischer 2001:92). Die persoon wat die boek Rut op skrif gestel het, kom egter heel waarskynlik uit dieselfde skrifgeleerde kringe as die EsraNehemia-groep en is op 'n oënskynlik onpolemiese wyse doelgerig besig om te reageer teen diegene wat stad, tempel en kultus beklemtoon.

\section{Slot}

Die tydperk van die Tweede Tempel, oftewel die Persiese tydperk, was 'n belangrike periode vir Israel se identiteitsvorming: etnies, kultureel en religieus. Die spil

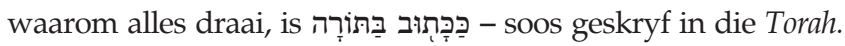
Gedurende hierdie tydperk ontstaan 'n fassinerende debat nie oor wat geskryf is nie - wat geskryf is, is immers geskryf - maar oor hoe die geskrewe Torah geïnterpreteer moet word. Minstens twee vertolkings kom direk teenoor mekaar te staan. Enersyds is daar die radikaal eksklusiewe skrywers van die boeke Esra en Nehemia wat reken dat Israel se identiteit bewaar moet word deur dit van alle vreemde elemente, soos huwelike met vreemde vroue, te suiwer. Andersyds is daar skrywers wat ' $n$ meer inklusiewe benadering bepleit, soos die skrywers van (trito-)Jesaja en die boek Rut.

Na alle waarskynlikheid het hierdie skrywers almal dieselfde

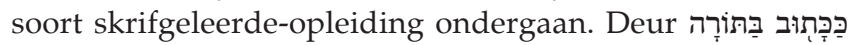
radikaal anders te interpreteer, kom hulle pen in die hand lynreg teenoor mekaar te staan. Een groep kleef hardnekkig vas aan - of dit nou regtig geskryf is of nie - om vreemdelinge weg te dryf. Die ander groep vermy die terme heeltemal, maar lewer deur middel van poësie of narratief 'n kragtige pleidooi om juis die deure oop te gooi vir diegene wat die Torah wil uitsluit. Deur te sing oor die nie-Israeliete en die ontmandes wat ook die kultiese bepalinge van die Torah onderhou, hulle wat lewe volgens die verbond van die Here, belowe Jesaja (56:3-8) aan die uitgeworpenes ook vrede en vreugde in die huis van die Here. Deur te skryf oor Rut, die Moabitiese, haar onbaatsugtige liefde tenoor haar Judese skoonmoeder, en veral die hoop wat uit die kind Obed - as voorvader van koning Dawid - straal, word daar 'n ander lig op vreemdelinge en vreemde vroue gewerp. In die pennevrug van hierdie laaste groep skrywers, is die Torah dus oop vir ander interpretasies. Die letter van die wet word dus uitgebrei tot die etiese en morele optrede van mense.

In die tydperk van die Tweede Tempel, word Israel se identiteit bepaal deur wat geskryf word. Naamlose skrywers stempel die wese van die volk, maar stem nogtans glad nie met mekaar saam nie. Sommige van hulle interpreteer die bestaande Torah volgens die letter van die wet, en skryf stories oor onverbiddelike, selfs gewelddadige eksklusivisme soos Numeri 25:6-13, Esra 10 en Nehemia 13:1-3. Ander, soos Trito-jesaja en Rut, onthou die kontra-insidente waarin vreemdelinge en verstotelinge nie net verwelkom word nie, maar ook vir Israel heil bring.

Nie die swaard nie, maar die pen besluit wie tot die gemeenskap van die Here behoort. Anders gestel: wie word ingeskryf, en wie word uitgeskryf?

Kortom, die pen is magtiger as die swaard.

\section{Erkenning Mededingende belange}

Die outeur verklaar dat sy geen finansiële of persoonlike verbintenis het met enige party wat haar nadelig kon beïnvloed in die skryf van hierdie artikel.

\section{Literatuurverwysings}

Barton, J. \& Bowden, J., 2004, The original story: God, Israel and the world, Darton, Longman and Todd Ltd., London. PMid:10776590

Boshoff, W., 2000a, 'The literature of the Northern Kingdom of Israel (922-721 BCE)', in W. Boshoff, E. Scheffler \& I. Spangenberg (eds.), Ancient Israelite literature in context, pp. 97-115, Protea Book House, Pretoria.

Boshoff, W., 2000b, 'The literature of the Southern Kingdom of Judah (922-586 BCE)', in W. Boshoff, E. Scheffler \& I. Spangenberg (eds.), Ancient Israelite literature in contex, pp. 116-141, Protea Book House, Pretoria.

Braulik, G., 1999, 'The Book of Ruth as intra-Biblical critique on the Deuteronomistic law', Acta Theologica 1, 1-20.

Carr, D.M., 2005, Writing on the tablet of the heart: Origins of Scripture and literature, Oxford University Press, New York.

Collins, J.J., 2003, 'The zeal of Phinehas: The Bible and the legitimation of violence', Journal of Biblical Literature 122(1), 3-21. http://dx.doi.org/10.2307/3268089

Crenshaw, J.L., 1985, 'Education in ancient Israel', Journal of Biblical Literature 104(4), 601-615. http://dx.doi.org/10.2307/3260674

Davies, P.R., 1998, Scribes and schools: The canonization of the Hebrew Scriptures, Westminster John Knox Press, Louisville.

Fischer, I., 2001, Rut. Herders Theologischer Kommentar zum Alten Testament, Herder, Freiburg im Bresgau.

George, A.R., 2003, The Babylonian Gilgamesh Epic: Introduction, critical edition and cuneiform texts, vol. 1, Oxford University Press, Oxford. PMCid:PMC3670791

Gerstenberger, E.S., 2005, Israel in der Perserzeit 5. und 4. Jahrhundert v Chr., Kohlhammer, Stuttgart.

Grabbe, L.L., 2004, A history of the Jews and Judaism in the Second Temple period, vol. 1:Yehud: A history of the Persian province of Judah, T\&T Clark International, London.

Holladay, W.L., 1988, A concise Hebrew and Aramaic lexicon of the Old Testament, E.J. Brill, Leiden.

Knoppers, G., 2011, "'Married into Moab": The exogamy practiced by Judah and his descendants in the Judahite lineages', in C. Frevel (ed.), Mixed marriages, intermarriage and group identity in the Second Temple period, pp. 170-191, T\&T Clark International, London.

Le Roux, J.H., 1987, 'Teologie in 'n krisis', in F.E. Deist \& J.H. le Roux (reds.), Rewolusie en reïnterpretasie: Die literatuur van die Ou Testament, deel 4, bl. 101-159, Tafelberg Uitgewers Beperk, Kaapstad.

Leuchter, M., 2010, 'Coming to terms with Ezra's many identities in Ezra-Nehemiah', in L. Jonker (ed.), Historiography and identity (Re)formulation in Second Temple historiographical literature, pp. 41-63, T\&T Clark International, London.

Nemet-Nejat, K.R., 2002, Daily life in Ancient Mesopotamia, Hendrickson Publishers, Peabody.

Nihan, C., 2011, 'Ethnicity and identity in Isaiah 56-66', in O. Lipschits, G.N. Knoppers \& M. Oeming (eds.), Judah and the Judeans in the Achaemenid period. Negotiating identity in an international context, pp. 67-104, Eisenbrauns, Winona Lake.

Pakkala, J., 2011, 'Intermarriage and group identity in the Ezra tradition (Ezra 7-10 and Nehemiah 8)', in C. Frevel (ed.), Mixed marriages, intermarriage and group identity in the Second Temple period, pp. 78-88, T\&T Clark International, London.

Pearce, L.E., 1995, 'Scribes and scholars in Ancient Mesopotamia', in J.M. Sasson (ed.), Civilizations of the Ancient NearEast, pp. 2265-2278, Scribner's Sons, New York. 
Quesada, J.J., 2002, 'Body piercing: The issue of priestly control over acceptable family structures in the Book of Numbers', Biblical Interpretation 10, 24-35. http://dx.doi. structures in the Book of Numbers',
org/10.1163/156851502753443272

Rollston, C.A., 2006, 'Scribal education in Ancient Israel: The old Hebrew epigraphic evidence', Bulletin of the American Schools of Oriental Research 344, 47-74.

Scharper, J., 2011, 'Torah and identity in the Persian period', in O. Lipschits, G.N. Knoppers $\&$ M. Oeming (eds.), Judah and the Judeans in the Achaemenid period. Negotiating identity in an international context, pp. 27-38, Eisenbrauns, Winona Lake.

Southwood, K, 2011, 'An ethnic affair? Ezra's intermarriage crisis against a context of "self ascription" and "ascription of others"', in C. Frevel (ed.), Mixed marriages, International, London.
Tov, E., 2004, Scribal practices and approaches reflected in the texts found in the Judean desert, Brill, Leiden.

Van der Toorn, K., 2007, Scribal culture and the making of the Hebrew Bible, Harvard University Press, Cambridge. PMCid:PMC1899328

Walker, C.B.F., 1996, 'Cuneiform', in J.T. Hooker (ed.), Reading the past, pp. 15-73, British Museum Press, London.

Weeks, S., 1994, Early Israelite wisdom, Clarendon, Oxford.

Williamson, H.G.M., 2010, 'Welcome home', in P.R. Davies \& D.V. Edelman (eds.), The historian and the Bible: Essays in honor of Lester Grabbe, pp. 113-123, T\&T Clark, London. 